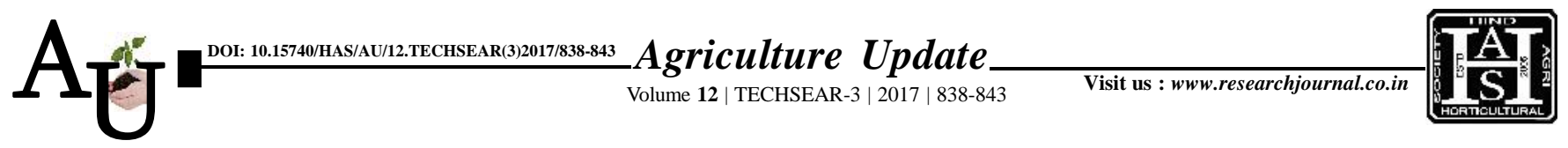

[ e ISSN-0976-6847

\title{
Research Article: Design and development of charcoal fuelled corn roaster
}

Article Chronicle : Received : 13.07.2017;

Accepted :

28.07.2017

KeY Words:

Dent corn, Sweet corn, Roaster, Sprocket speed, Roasting time

Author for correspondence :

\section{TANMAY}

College of Agricultural

Engineering (PJTSAU), SANGAREDDY

(TELANGANA) INDIA

Email : tanmaymandala

@ gmail.com

See end of the article for authors' affiliations

\section{S.K. KARTHIK, M. TANMAY, B. SUMANTH, T. MAHESH, M. JAHNAVI, V. VIDYADHARI AND G. RAVALI}

SUMMARY : In India, roasted corn is a popular snack which is sold on the roadsides by street vendors. However, consumers have become more health conscious and are slowly becoming aware of the ill-effects caused to their health upon consuming the roasted corn. This problem has arisen owing to the adherence of charcoal ash onto the corns as they are roasted directly on the charcoal cinders without any protective covering. Consequentially, the vendors not afford better technology needed for roasting them. Addressing the mentioned issues, a charcoal-fuelled corn roaster was developed and tested for its roasting efficiency on two corn varieties namely, Dent corn and Sweet corn. The roaster was integrated with a fan to blow air onto the charcoal cinders and keep them red-hot. Provision was made to vary the speed of the driving sprocket and roasting time. The effects of the sprocket speed $(0,70$ and $100 \mathrm{rpm})$ and roasting time $(2,3$, and 4 minutes) on percentage of roasted kernels, percentage of over roasted kernels, roasting efficiency and roasting capacity of the developed roaster were studied. For optimum roasting efficiency of the roaster, $100 \mathrm{rpm}$ sprocket speed and roasting times of 4 minutes and 3 minutes were found appropriate for roasting Dent Corn and Sweet Corn, respectively. The cost of roasting corns with the developed roaster was Rs. 0.578 per corn and the Cost: Benefit ratio was worked out to be 1.00:5.19. The developed Corn Roaster was found to be advantageous for roasting the selected corn varieties.

How to cite this article : Karthik, S.K., Tanmay, M., Sumanth, B., Mahesh, T., Jahnavi, M., Vidyadhari, V. and Ravali, G. (2017). Design and development of charcoal fuelled corn roaster. Agric. Update, 12(TECHSEAR-3) : 838-843; DOI: 10.15740/HAS/AU/12.TECHSEAR(3)2017/838-843. 